\title{
Postpartum Uterine Infections in Cows and Factors Affecting it- A Review
}

\author{
Akshay Sharma*, Madhumeet Singh, Pravesh Kumar, Amit Sharma, \\ Neelam, Aaqib Majid Jan and Pranshu Sharma
}

\author{
Department of Veterinary Gynecology and Obstetrics, College of Veterinary and Animal \\ Sciences, Himachal Pradesh Agricultural University, Palampur - 176062, India \\ *Corresponding author
}

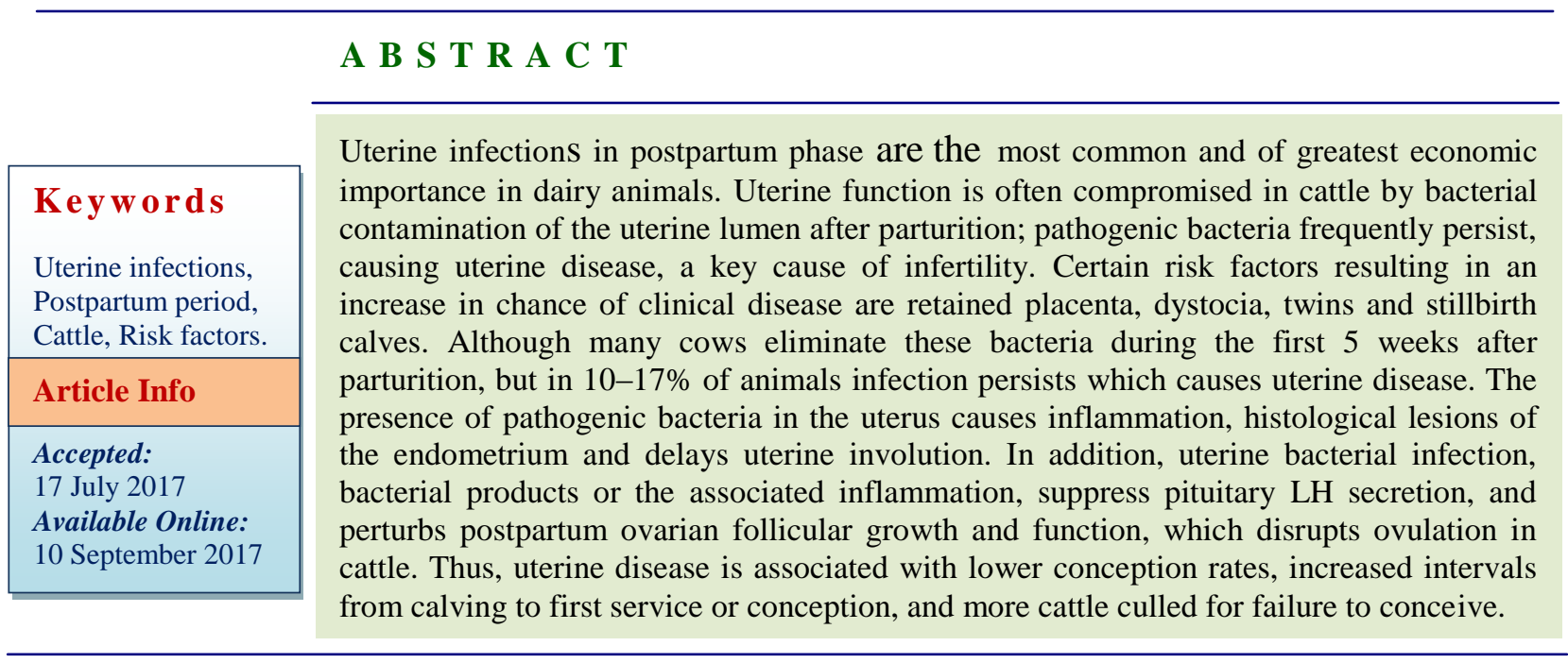

\section{Introduction}

Postpartum reproductive health in dairy cattle is judged by complete uterine involution (return to its normal size and position), free from infection and for cows to have cyclic activities by the time they enter the breeding period (LeBlanc, 2002; Gautam et al., 2009).

80 to $100 \%$ of cows will have bacterial contamination within the uterus after parturition. Cows with abnormal vaginal discharge are more likely to have an increased an ovulatory period or extended postpartum luteal phases. Cows diagnosed with endometritis have $20 \%$ lower conception rates and the average interval from calving to conception is 30 days longer. Decrease in reproductive performance is seen even after cows are successfully treated for endometritis. Sub-clinical endometritis can persist after outward signs resolve which result in an increase in number of days open and more services per conception (Sheldon et al., 2009).

Postpartum uterine infections can delay the regeneration of endometrium and disrupt the resumption of cyclic ovarian function which leads to the postponement of first insemination (AI), increase in number of inseminations per conception and thus calving interval is prolonged (Foldi et al., 2006). 
LeBlanc et al., (2002) reported that conception rate was $20 \%$ lower in cows with endometritis, and calving to conception interval increases by 30 days and about $35 \%$ more animals were culled for failure to conceive.

Reduced fertility due to postpartum infection can increase the amount of hormones used for synchronization as well as multiple doses of semen due to increased services per conception. Milk production is reduced due to the reproductive tract infection. Also, treatment affects the individual due to high expenses and can reduce the amount of saleable milk due to milk-withdrawal periods. Culling rates also increase when the cow fails to conceive (Sheldon et al., 2009).

\section{Postpartum uterine infection}

Postpartum period is defined as the period after parturition and lasts until reproductive function is restored so that another pregnancy can occur. There are four major events during this period which include: myometrial contractions and expulsion of secundus, endometrial repair, resumed ovarian function and elimination of bacterial contamination in the reproductive tract (Senger, 2012). Secundus begins three days postpartum, reaches its peak during second week and all the fluid is normally expelled by 18 days postpartum (Olson et al., 1986). Viscous consistency of normal secundus changes to foul smelling watery and reddish brown exudates because atonic uterus is not able to expel its content during puerperal metritis (Smith and Risco, 2002) and increases the risk of bacterial complications (Sheldon and Dobson, 2004). Uterine involution consists of the reduction in uterine size, clearing bacterial contamination, sloughing of caruncles and regeneration of the endometrium (Sheldon et al., 2008) and is completed by 28 days postpartum (Saut et al., 2011). Resumption of cyclicity also occurs during this interval, with the first ovulation occurring around days 40 to 45 postpartum (Cengic et al., 2012). This interval can be affected by nutrition, body condition, parity and can be extended due to uterine disease (Sheldon et al., 2002).

Bacterial contamination of uterine lumen after parturition often hinders the uterine function (Sheldon and Dobson, 2004). Bacteria can be cultured from samples collected from uterine lumen of dairy cattle in the first 2 weeks after parturition without appearance of any apparent clinical signs (Sheldon et al., 2002).

Polat et al., (2009) reported that $10-17 \%$ of cows have pathogenic bacteria two weeks post-calving while Sheldon (2007) found that intensively managed dairy cattle often have bacterial uterine contamination rates of 90 to $100 \%$ within the first two weeks postpartum. Prevalence of clinical and sub-clinical endometrits after parturition ranges between 5 to $>30 \%$ and 11 to $>70 \%$, respectively (Galvao et al., 2009).

Uterine infections can be classified as puerperal metritis, clinical endometritis, subclinical endometritis and pyometra (Sheldon, 2004; Sheldon et al., 2008).

\section{Puerperal metritis}

Metritis is a severe inflammatory response that occurs within all the layers of the uterus including the endometrium, submucosa, myometrium and perimetrium. Puerperal metritis usually occurs within Day 10 postpartum and is defined as an acute systemic illness caused by an infection of the uterus (Sheldon et al., 2006). Important characteristic of puerperal metritis is rectal temperature greater than $39.5^{\circ} \mathrm{C}$ within 21 days after calving. Retained placenta, fetal maceration or difficult calvings are predisposing factors for occurrence of 
puerperal metritis (Foldi et al., 2006; Chapwanya, 2008). Up to $40 \%$ animals develop metritis within the first fourteen days of calving and 10 to $15 \%$ of these animals have infection for at least another three weeks leading to a chronic uterine disease known as endometritis (Sheldon and Dobson, 2004).

\section{Endometritis}

In postpartum cows, endometritis continues to be a major cause of poor fertility and delayed conceptions (Couto et al., 2013). Two important types of endometritis have been recently recognized as the clinical and subclinical endometritis (Barlund et al., 2008). Such cows do not show any signs of systemic illness (Sheldon, 2004).

Clinical endometritis is defined as a purulent or mucopurulent discharge or a cervical diameter $>7.5 \mathrm{~cm}$ after 20 days in milk (DIM) or mucopurulent discharge after 26 DIM (LeBlanc et al., 2002). Cows with endometritis have deeper uterine tissue involvement, higher degrees of bacterial contamination (Foldi et al., 2006). Endometritis is defined as inflammation of mucus membrane of uterus and presence of mucopurulent to purulent discharge in uterus after three weeks of parturition or later (Turk et al., 2011). Clinical findings by rectal palpation of the uterus are asymmetric uterine horns, thickened uterine wall and palpable presence of fluid during clinical endometritis (Lewis, 1997).

Sub-clinical endometritis is characterized by scanty exudates accumulated in uterus resulting in complete lack of cervical discharge with pathognomic property (Kasimanickam et al., 2004; Gilbert et al., 2005) and can be diagnosed by endometrial cytology if purulent discharge is absent in the vagina (Gilbert et al., 1998). Sub-clinical endometritis can be defined by greater than
$18 \%$ neutrophils in uterine cytology samples at 20-33 days or greater than $10 \%$ neutrophils at 34-47 days postpartum (Sheldon et al., 2006).

\section{Pyometra}

Pyometra is defined as accumulation of purulent exudate of variable amount in the uterine lumen. Cows having first postpartum ovulation, before bacterial contamination of the uterus has been eliminated, are most likely to develop pyometra (Foldi et al., 2006; Chapwanya, 2008). Pyometra is characterized by the presence of corpus luteum on ovary and accumulation of fluid of mixed echodensity in the uterine lumen and distention of the uterus on ultransonographic examination (Manns et al., 1985). There is functional closure of the cervix but the lumen is not always completely closed and some pus may discharge through the cervix into the vaginal lumen (Sheldon et al., 2006). Prolongation of the luteal phase may be attributed to increased concentrations of luteotrophic prostaglandin PGE2 associated with endometrial bacterial infection. Pyometra can occur if ovulation occurs too early in the postpartum period and corpus luteum is formed during uterine infection (Sheldon et al., 2008).

Return of ovarian cyclic activity postpartum depends on the uterine immune response. High concentration of progesterone during luteal phase suppresses the immune response of the uterus and makes the uterus more susceptible to bacterial infection (Lewis, 2003). Negative effects of corpus luteum on the early postpartum uterus can be attributed to progesterone. Myometrium relaxation occurs due to effect of progesterone and hinders the clearing of bacterial contamination of uterus (Bonafos et al., 1995). Also, increase in plasma progesterone concentration leads to decreased phagocytic 
activity of both uterine and peripheral blood neutrophils (Dhaliwal et al., 2001).

\section{Factors affecting postpartum reproductive function}

Condition of the postpartum reproductive tract is related to many attributes. Various factors such as puerperal condition, parity, season of calving, age of dam, level of feeding, suckling have influence on postpartum fertility of cattle (Zain et al., 1995).

\section{Parity}

Rekwot et al., (2000) concluded that uterine involution is rapid in pluriparous cows after examining cows for first 20 days postpartum. Onset of postpartum ovarian activity may take longer interval in primiparous cows (Lucy et al., 1992). Days from calving to ovulation (first and second) and the number of follicular waves to first ovulation are more in primiparous cows than in multiparous cows. Parity, postpartum uterine involution and resumption of ovarian activity are negatively related to each other (Zhang et al., 2010).

Uterine infections develop in cows having parity greater than 3 due to delayed involution of uterus and chances of endometritis after 3 weeks of parturition are more. Heifers and cows having parity less than three tend to develop puerperal metritis because of uterine tissue damage during dystocia (Bruun et al., 2002). Uterine infections just after parturition affect the reproductive function of cow (Kim and Kang, 2003). Primiparous cows are at higher risk of clinical endometritis compared to second-parity cows (Aghamiri et al., 2014).

\section{Season}

Calving season also affects postpartum reproductive function. Early involution occurs in dry season than in rainy season (Rekwot et al., 2000). Elmetwally et al., (2016) recorded that ovarian cyclicity resumes much earlier in spring season as compared to winter season. Campo et al., (2002) found no significant effect on uterine involution period due to calving season.

Buckley et al., (2010) reported a positive association between retention of foetal membranes with a seasonal pattern on the incidence of uterine infections. Reduced feed intake during winter season resulting in negative energy balance leads to metritis. Also, immunosupression and decreased leukocyte activity during winter increases the risk of uterine infection (Onyango, 2014). Winter months and stabling mean lack of grazing, increased energy expenditure for maintenance, different feed, overcrowding, reduced exercise and less access to sunlight increases the risk of postpartum uterine disease (Cady, 2010).

\section{Age of dam}

Gunduz et al., (2010) found that age was highly significant in the presentation of uterine infections. Brunn et al., (2002) found high incidence of uterine infection at an early age. Lowest incidence of postpartum metritis occurred in cows between 2 and 4 years of age and was highest in cows older than 7 years (Smith and Risco, 2002). Young cows are prone to uterine injuries during assisted calving and thus predisposing them to uterine infections (Konyves et al., 2009; Tsousis et al., 2009). Cows aged between 2-4 years have a small pelvis compared to older cows and thus greater degree of uterine damage leads to uterine infection (Potter et al., 2010).

Tsousis et al., (2009) found out that cows in their first parity had persistent purulent discharge compared to older cows which could have been as a result of calving 
assistance leading to uterine lesions. Endometritis was more prevalent in mature cows where cows in their third or higher lactation had a prevalence of $21 \%$ compared to $13 \%$ for cows in first and second lactation (LeBlanc et al., 2002).

\section{Dystocia}

Dystocia is defined as complications developed during calving which often results in postpartum uterine infections (Foldi et al., 2006; Tsousis et al., 2009). Dystocia results in injury to uterine tissue which can easily be invaded by pathogens and leads to uterine infection (Kim and Kang, 2003). Oversized or malpresented calf can cause injuries to the genital tract during traction and retropulsion and thus create septic conditions which may result in infections (Zaborski et al., 2009). Dystocia delays the process of complete parturition by disturbing the hormonal events resulting in placenta retention and predisposing cows to uterine infection (Smith and Risco, 2002).

Multiple births increased the odds for dystocia which was also involved in the aetiology of post-parturient infections (Hossein-Zadeh, 2010). Trauma during dystocia and caesarean section leads to release of heparin (at the site of injury) which inhibits collagenases and can also delay uterine involution and contribute to retention of foetal membranes (Beagley et al., 2010).

\section{Retention of Foetal Membranes (RFM)}

Retention of foetal membranes in cattle can lead to adverse health effects that ultimately affect reproductive performance. In cattle, failure to expel foetal membranes within 12 to 24 hours is termed as RFM (Drillich et al., 2003). Decrease in the antioxidant enzyme capacity of the placenta during pregnancy can also contribute to the etiology of RFM. Lower prepartum levels of placental superoxide dismutase and plasma estrogen were found in cows which subsequently developed RFM (Gupta et al., 2005). Normal detachment of the bovine placenta involves separation of the finger-like cotyledon villi from the caruncle crypts. Dystocia and uterine trauma have been associated with uterine atony that could inhibit expulsion of membranes and lead to secondary retention (Au et al., 1992; Eiler and Fecteau, 2007). Vitamin E and selenium can increase chemotaxis and leukocyte numbers at the fetomaternal junction, thus contributing to the normal expulsion of fetal membranes (Bourne et al., 2007).

Opsomer and Kruif (2009) stated that contamination of the uterus by pathogens which had RFMs and dystocia can affect fertility due to the disruption of the normal endocrine control of ovarian activity, disrupted follicular development, have tendency to prevent the establishment of pregnancy by the presence of pathogenic organisms in the uterine lumen and have two times higher risk of metritis with a subsequent effect on fertility. Infections generally gain entry during calving and frequently associated with difficult birth (dystocia) and Retention of Fetal Membranes (RFM).

Under normal condition the microorganisms are eliminated from the uterus during uterine involution by the normal Uterine Defense Mechanism (UDM). However, when the UDM is compromised due to various factors the clinical symptoms of metritis sets in and sometimes leads to the death of the animal (Deori and Phookan, 2015).

Negative squeal to RFM include delayed uterine involution, longer time to 1 st service, increased services per conception, decreased pregnancy rates and increased days open. RFM also have been associated with increased risk for endometritis, metritis, ketosis, and mastitis (McDougall, 2001; Bruun et al., 2002). 
In conclusion, postpartum uterine infection is the most important cause of infertility in dairy animals. Various predisposing factors like dystocia, RFM, still birth, caesarean section play an important role in establishment of the uterine infections. Extent of uterine infection depends on the immune response of the cow as well as the species and number (load or challenge) of bacteria. The infectious agents colonize and penetrate the mucosal epithelium and/or release bacterial toxins that lead to establishment of uterine infection. As uterine infections affect the cyclicity of animal, intrauterine transport of sperm and embryo implantation thus leading to delayed calving to first service interval and reduced conception rates posing huge economic losses to the farmers, therefore, proper nutrition during pregnancy, hygienic conditions during calving and immediate veterinary care in case of dystocia is required to limit the postpartum uterine infections.

\section{References}

Aghamiri, S.M., Haghkhah, M., Ahmadi, M.R. and Gheisari, H.R. 2014. Development of a Multiplex PCR for the identification of major pathogenic bacteria of post-partum endometritis in dairy cows. Reproduction in Domestic Animals, 49, 233-238.

$\mathrm{Au}$, Y.P., Montgomery, K.F. and Clowes, A.W. 1992. Heparin inhibits collagenase gene expression mediated by phorbol ester-responsive element in primate arterial smooth muscle cells. Circulation Research, 70, 1062-1069.

Barlund, T.D., Carruthers, T.D., Waldner, C.L. and Palmer, C.W. 2008. A comparison of diagnostic techniques for postpartum endometritis in dairy cows. Theriogenology, 69, 714-723.

Beagley, J.C., Whitman, K.J., Baptiste, K.E. and Scherzer, J. 2010. Physiology and treatment of retained foetal membranes in cattle. Journal of Veterinary Internal Medicine 24, 261-268.

Bonafos, L., Kot, K. and Ginther, O. 1995. Physical characteristics of the uterus during the bovine estrous cycle and early pregnancy. Theriogenology 43, 713-721.

Bourne, N., Laven, R. and Wathes, D.C. 2007. A meta-analysis of the effects of vitamin $\mathrm{E}$ supplementation on the incidence of retained foetal membranes in dairy cows. Theriogenology 67, 494501.

Bruun, J., Ersbull, A.R. and Alban, L. 2002. Risk factors for metritis in Danish dairy cows. Preventive Veterinary Medicine 54, 179-190.

Buckley, F., Dillon, P. and Mee, J.F. 2010. Major management factors associated with the variation in the reproductive performance in Irish dairy herds. Final Report Project, 5070.

Cady, R.A., 2010. Dystocia-difficult calving, what it costs and how to avoid it. Dairy International

Reproduction Management, 20, 1-5.

Campo, E., Alonso, J.C., Hincapie, J.J., Garcia, L., Faure, O. and Fernandez, O. 2002. Seasonal influence on uterine involution and postpartum ovarian activity in river buffaloes. Bubalus bubalis, 8(3), 59-63.

Cengic, B., Varatanovic, N., Mutevelic, T., Katica, A., Mlaco, N. and Cutuk, A. 2012. Normal and abnormal uterine involution in cows monitored by ultrasound. Biotechnology in Animal Husbandry, 28(2), 205-217.

Chapwanya, A., 2008. Uterine disease in dairy cows: classification, diagnosis and key role of veterinarians. Irish Veterinary Journal, 61(3), 183-186.

Couto, G.B., Vaillancourt, D.H. and Lefebvre, R.C. 2013. Comparison of leucocyte esterase test with endometrial cytology for diagnosis of subclinical endometritis 
in postpartum dairy cows. Theriogenology, 79, 103-107.

Deori, S., and Phookan, A. 2015. Bovine Postpartum Metritis and its Therapeutics: A Review. Indian Journal of Science and Technology 8(23), 1-5. http://www.indjst.org/index.php/indjst/a rticle/view/52386/61468

Dhaliwal, G., Murray, R. and Woldehiwet, Z. 2001. Some aspects of immunology of the bovine uterus related to treatments for endometritis. Animal Reproduction Science, 67, 135-152.

Drillich, M., Pfutzer, A. and Sabin, H.J. 2003. Comparison of two protocols for treatment of retained fetal membranes in dairy cattle. Theriogenology, 59: 951-960.

Eiler, H., and Fecteau, K.A. 2007. Retained placenta. In: Youngquist, R.S. and Threlfall, W.R. editors. Current Therapy in Large Animal Theriogenology, 2nd edition St Louis, MO: WB Saunders. pp 345-354.

Elmetwally, M.A., Montaser, A., Elsadany, N., Bedir, W., Hussein, M. and Zaabel, S. 2016. Effects of Parity on Postpartum Fertility Parameters in Holstein Dairy Cows. IOSR Journal of Agriculture and Veterinary Science, 9, 91-99.

Foldi, J., Kulksar, M., Pecsi, A. and Lohuis, J.A.C.M. 2006. Bacterial complications of postpartum uterine involution in cattle. Animal Reproduction Science, 96, 265-281.

Galvao, K.N., Greco, L.F., Vilela, J.M., Safilho, M.F. and Santos, J.E.P. 2009. Effect of intrauterine infusion of ceftiofur on uterine health and fertility in dairy cows. Journal of Dairy Science, 92, 1532-1542.

Gautam, G., Nakao T., Yusuf, M. and Koike, K. 2009. Prevalence of endometritis during the postpartum period and its impact on subsequent reproductive performance in two Japanese dairy herds. Animal Reproduction Science, 116(3-4), 175-187.

Gilbert, R.O., Shin, S.T., Guard, C.L. and Erb, H.N. 1998. Incidence of endometritis and effects on reproductive performance of dairy cows. Theriogenology, 49, 251.

Gilbert, R.O., Shin, S.T., Guard, C.L., Erb, H.N. and Frajblat, M. 2005. Prevalence of endometritis and its effects on reproductive performance in dairy cows. Theriogenology, 64, 1879-1888.

Gunduz, M.C., Sabuncu, A., Ucmak, M., Kasikci, G. and Tek, C. 2010. Postpartum reproductive problems and therapy in dairy cows. Journal of Animal and Veterinary Advances, 9, 1952-1954.

Gupta, S., Gupta, H. and Soni, J. 2005. Effect of vitamin $\mathrm{E}$ and selenium supplementation on concentration of plasma cortisol and erythrocyte lipid peroxidases and the incidence of retained fetal membranes in crossbred dairy cattle. Theriogenology, 64, 12731286.

Hossein-Zadeh, N.G., 2010. The effect of twinning on milk yield, dystocia, calf birth weight and open days in Holstein dairy cows of Iran. Journal of Animal Physiology and Animal Nutrition, 94, 780-787.

Kasimanickam, T.F., Duffield, R.A., Foster, C.L., Gartley, K.E., Leslie, J.S. and Johnson, W.H. 2004. Endometrial cytology and Ultrasonography for the detection of subclinical endometritis in postpartum dairy cows. Theriogenology, 62, 9-23.

Kim, I.H., and Kang, H.C. 2003. Risk factors for postpartum endometritis and the effect of endometritis on reproductive performance in dairy cows in Korea. Journal of Reproduction and Development, 49, 485-491.

Konyves, L., Szenci, O., Jurkovich, V., 
Tegzes, L., Tirian, A., Solymosi, N., Gyulay, G. and Brydl, E. 2009. Risk assessment of postpartum uterine disease and consequences of puerperal metritis for subsequent metabolic status, reproduction and milk yield in dairy cows. Acta Veterinaria Hungarika, 57, 155-169.

LeBlanc, S.J., Duffield, T.F., Leslie, K.E., Keefe, G.P., Walton, J.S. and Johnson, W.H. 2002. Defining and diagnosing clinical endometritis and its impact on reproductive performance in dairy cows. Journal of Dairy Science, 85, 2223-2236.

Lewis, G.S., 1997. Uterine health and disorders. Journal of Dairy Science, 80, 984-994.

Lewis, G.S., 2003. Steroidal regulation of uterine resistance to bacterial infection in livestock. Reproductive Biology and Endocrinology, 1, 117.

Manns, J., Nkuuhe, J. and Bristol, F. 1985. Prostaglandin concentrations in uterine fluid of cows with pyometra. Canadian Journal of Comparative Medicine, 49, 436-438.

McDougall, S., 2001. Effects of periparturient diseases and conditions on the reproductive performance of New Zealand dairy cows. New Zealand Veterinary Journal, 49:60-68.

Olson, J.D., Bretzlaff, K. and Mortimer, R.G. 1986. The metritis-pyometra complex: Current Therapy in Theriogenology. Philadelphia, WB Saunders Corporation. p 227

Onyango, J., 2014. Cow postpartum uterine infection: A review of risk factors, prevention and the overall impact. Veterinary Research International, 2, 18-32.

Opsomer, G., and Kruif, A. 2009. Metritis and endometritis in high yielding dairy cows. Vlaams Diergeneeskundig Tijdschrift, 78, 83-88.
Polat, B., Kirecci, E., Kapakin, K.A.T. and Kolak, A. 2009. Fertility parameters of dairy cows with retained placenta or endometritis treated with intrauterine providone iodine foam. Veterinary Institute Pulawy, 53, 395-400.

Potter, T.J., Guitian, J., Fishwick, J., Gordon, P.J. and Sheldon, I.M. 2010. Risk factors for clinical endometritis in postpartum dairy cattle. Theriogenology, 74, 127- 134.

Rekwot, P.I., Ogwu, D. and Oyedipe, E.O. 2000. Influence of bull biostimulation, season and parity on resumption of ovarian activity of Zebu (Bos indicus) cattle following parturition. Animal Reproduction Science, 63(1-2), 1-11.

Saut, J.P.E., Oliviera, R.S.B.R., Martins, C.F.G., Moura, A.R.F., Tsuruta, S.A., Nasciutti, N.R., Santos, R.M. and Headley, S.A. 2011. Clinical observations of postpartum uterine involution in crossbred dairy cows. Veterinaria Noticias, 17(1), 16-25.

Senger, P.L., 2012. Pathways to Pregnancy and Parturition, Third Edition. Current Conceptions Inclusive, pp. 124-126.

Sheldon, I.M., 2004. The postpartum uterus. Veterinary Clinics of North America: Food Animal Practice, 20, 569-591.

Sheldon, I.M., 2007. Endometritis in cattle: pathogenesis, consequences for fertility, diagnosis and therapeutic recommendations. Reproduction Management Bulletin, 2, 1-5.

Sheldon, I.M., and Dobson, H. 2004. Postpartum uterine health in cattle. Animal Reproduction Science, 82/83, 295-306.

Sheldon, I.M., Cronin, J., Goetze, L., Donofrio, G. and Joachim-Schuberth, H. 2009. Defining Postpartum Uterine disease and the mechanisms of infection and immunity in the female reproductive tract in cattle. Biology of Reproduction, 81, 1025-1032. 
Sheldon, I.M., Lewis, G.S., LeBlanc, S. and Gilbert, R.O. 2006. Defining postpartum uterine disease in cattle. Theriogenology, 65, 1516-1530.

Sheldon, I.M., Noakes, D.E., Rycroft, A.N., Pfeiffer, D.U. and Dobson, H. 2002. Influence of uterine bacterial contamination after parturition on ovarian dominant follicle selection and follicle growth and function in cattle. Reproduction, 123, 837-845.

Sheldon, I.M., Rycroft, A.N. and Zhou, C. 2004. Association between postpartum pyrexia and uterine bacterial infection in dairy cattle. Veterinary Record, 154(10), 289-293.

Sheldon, I.M., Williams, E.J., Miller, A.N.A., Nash, D.M. and Herath, S. 2008. Uterine diseases in cattle after parturition. The Veterinary Journal, $176,115-121$.

Smith, B.I., and Risco, C.A. 2002. Predisposing factors and potential causes of postpartum metritis in Dairy cattle. Food Animal Compendium, 24, 56-63.

Tsousis, G., Sharifi, R. and Hoedemaker, M. 2009. Association between clinical signs of chronic endometritis with ovarian cysts and body condition loss in German Holstein Friesian cows. Journal of Veterinary Science, 10, 337341.

Turk, R., Samardzija, M. and Bacic, G. 2011. Oxidative stress and reproductive disorders in dairy cows. In Dairy Cows: Nutrition, Fertility and Milk Production, (Marek, E. R., Ed.). New York: Nova Science Publishers, pp. 57-98.

Zaborski, D., Grzesiak, W., Szatkowska, I., Dybus, A., Muszynska, M. and Jedrzejczak, M. 2009. Factors affecting dystocia in cattle. Reproduction in Domestic Animals, 44, 540-551.

Zain, A.E.D., Nakao, T., Raouf, M.A., Moriyosh, M., Kawataa, K. and Moritsu, Y. 1995. Factors in the resumption of ovarian activity and uterine involution in postpartum dairy cows. Animal Reproduction Science, 38(3), 203-214.

Zhang, J., Deng, L.X., Zhang, H.L. and Yang, L. 2010. Effects of parity on uterine involution and resumption of ovarian activities in postpartum Chinese Holstein dairy cows. Journal of Dairy Science, 93(5), 1979-1986.

\section{How to cite this article:}

Akshay Sharma, Madhumeet Singh, Pravesh Kumar, Amit Sharma, Neelam Aaqib Majid Jan and Pranshu Sharma. 2017. Postpartum Uterine Infections in Cows and Factors Affecting it- A Review. Int.J.Curr.Microbiol.App.Sci. 6(9): 1020-1028. doi: https://doi.org/10.20546/ijcmas.2017.609.123 